\title{
53. PRELIMINARY RESULTS OF A SEISMIC REFRACTION STUDY IN THE MERIADZEK-TREVELY AN AREA, BAY OF BISCAY ${ }^{1}$
}

\author{
Félix Avedik, Centre Océanologique de Bretagne, Brest, France \\ and \\ David Howard, Dublin Institute for Advanced Studies, Geophysical Section, Dublin, Ireland
}

\begin{abstract}
Seismic refraction studies over the Meriadzek-Trevelyan area in the north of the Bay of Biscay have established four main geological sequences: Cenozoic (1.9 to $2.8 \mathrm{~km} / \mathrm{s}$ ); Cretaceous ( 3.2 to $4.0 \mathrm{~km} / \mathrm{s}$ ); lower to middle Mesozoic (4.5 to $5.0 \mathrm{~km} / \mathrm{s}$ ); pre-Mesozoic (5.4 to 6.3 $\mathrm{km} / \mathrm{s})$.

These agree broadly with the adjoining Western Approaches and English Channel areas to the northeast. The sub-sedimentary structure between the Meriadzek Terrace and the Trevelyan escarpment is of continental origin having a block-faulted pattern and is interpreted as a southwestward prolongation of the continental structure. The blockfaulted form is considered to have originated during the rifting of the Armorican Continental margin and may have been influenced by a tectonic pattern caused by the earlier activity of the South Armorican shear zone.
\end{abstract}

\section{INTRODUCTION}

In March and April 1976 several refraction profiles were shot during the "Margas 76" cruise by the Centre Océanologique de Bretagne on both sides of the continental slope, in the northern part of the Bay of Biscay and the Western Approaches. The area covered lies roughly between $45^{\circ}$ and $49^{\circ} \mathrm{N}$ and $4^{\circ}$ and $10^{\circ} \mathrm{W}$ (Figure 1). The objective of this survey was twofold: (a) to study the sub-surface geological structure in the Meriadzek-Trevelyan area in the vicinity of DSDP Sites 400 to 402 ; (b) to explore the deep structure of the "transition zone," the junction of the oceanic and continental crust.

In this paper we present results obtained from the interpretation of these refraction profiles. Incorporated are results from other refraction surveys, notably those of Bacon et al. (1969), Hill and Laughton (1952), Ewing and Ewing (1959), Bamford and Blundell (1970), and Holder and Bott (1971).

\section{GEOLOGICAL SETTING}

The two Paleozoic landmasses of Brittany and Cornwall (Figure 2) border the continental shelf of the Bay of Biscay to the northeast of the area of Figure 1. These land areas mainly are composed of Precambrian to Carboniferous strata in different stages of metamorphism. The oldest structural trend (NE-SW) recognized in northeastern Brittany relates most likely of the Cadomian orogeny (550-600 m.y.). The interfingering of Devonian marine

'Contribution 589 du Département Scientifique, Centre Océanologique de Bretagne. facies with Old Red Sandstone deposits in Cornwall and Brittany suggests that the southern shoreline of the Old Red Sandstone Continent stretched across the area. The Hercynian orogeny, accompanied by extensive metamorphic and intrusive activity, involved the development of large eastwest and northwest-southwest trending arches through Brittany and Cornwall, land areas which have since remained emerged, undergoing considerable erosion.

In the Western Approaches and the English Channel the Hercynian arches formed at least three distinctive northwest-woutheast basement ridges: the Start PointCotentin, Lizard-Brittany, and the basement high culminating at about $48^{\circ} 30^{\prime} \mathrm{N}$ and 7 to $8^{\circ} \mathrm{W}$ (Avedik, 1975). Also, a Hercynian granite batholith ridge runs roughly southwest from Lands End towards the continental shelf edge. Between this batholith ridge and a large northeastsouthwest-running fault complex (North Armorican Fault), close to Brittany, a major trough developed, presumably following the older tectonic event. From recent geological and geophysical evidence, the trough is filled with Permo-Triassic and marine-type Jurassic and Cretaceous sediments following a large west to east transgressive phase. The total sedimentary thickness in the trough is about $5 \mathrm{~km}$.

South of the North Armorican Fault, (Figure 2), on the Armorican continental shelf, due to the lower subsidence rate of the periphery of the Armorican Craton, only about $1.5 \mathrm{~km}$ of marine sediments accumulated, wedging out landwards.

A quite outstanding morphological feature of the blockfaulted Armorican continental margin is the Meriadzek-Trevelyan complex, which, as already suggested by several 


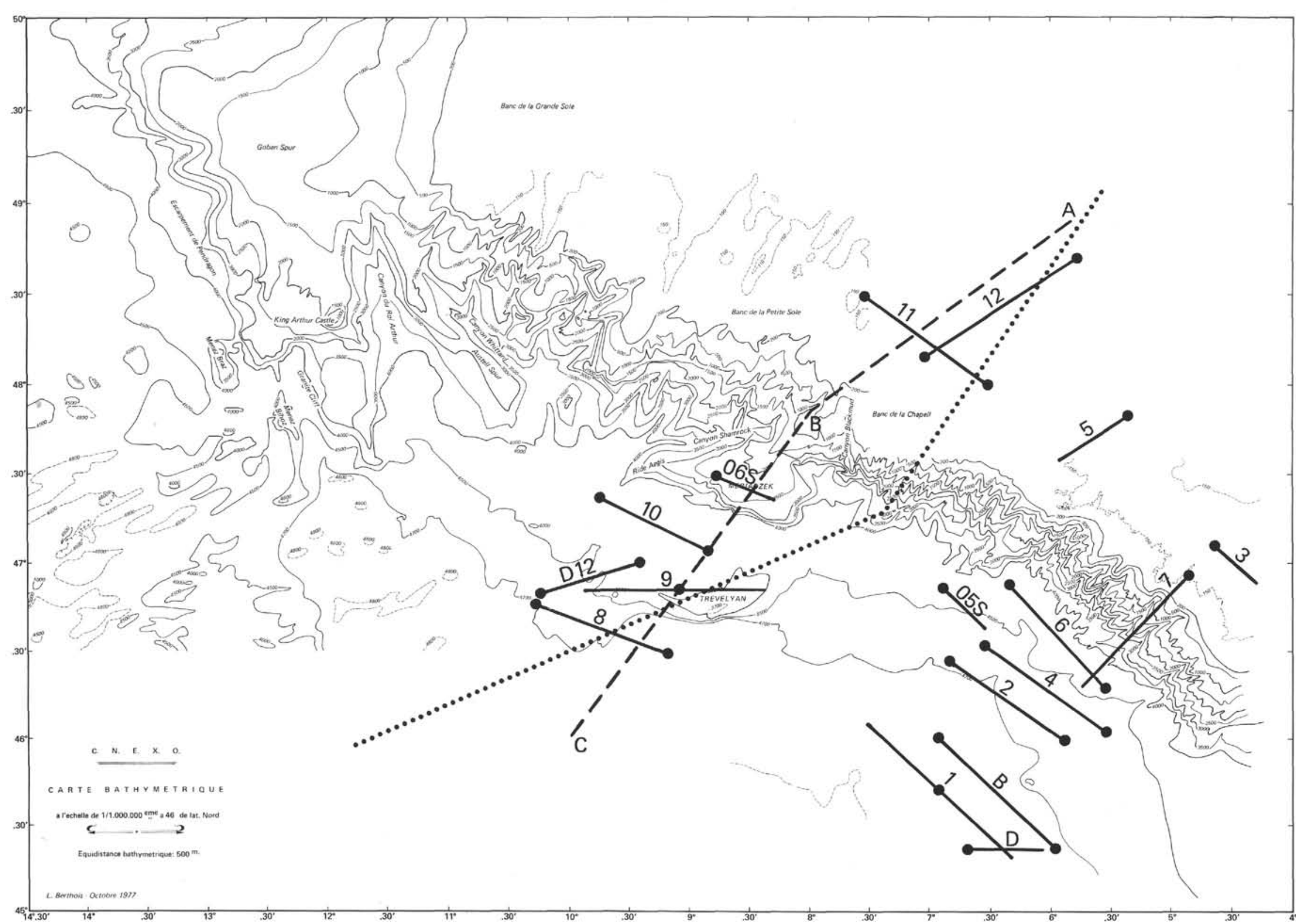

Figure 1. Bathymetric map of the area covered by the "Margas 76" cruise of the Centre Océanologique de Bretagne showing location of profiles. The broken heavy line A-B-Cmarks the position of the geological cross-section of Figure 6. The dotted line shows the track of the free-air gravity profile of Bacon and Gray (1971). 


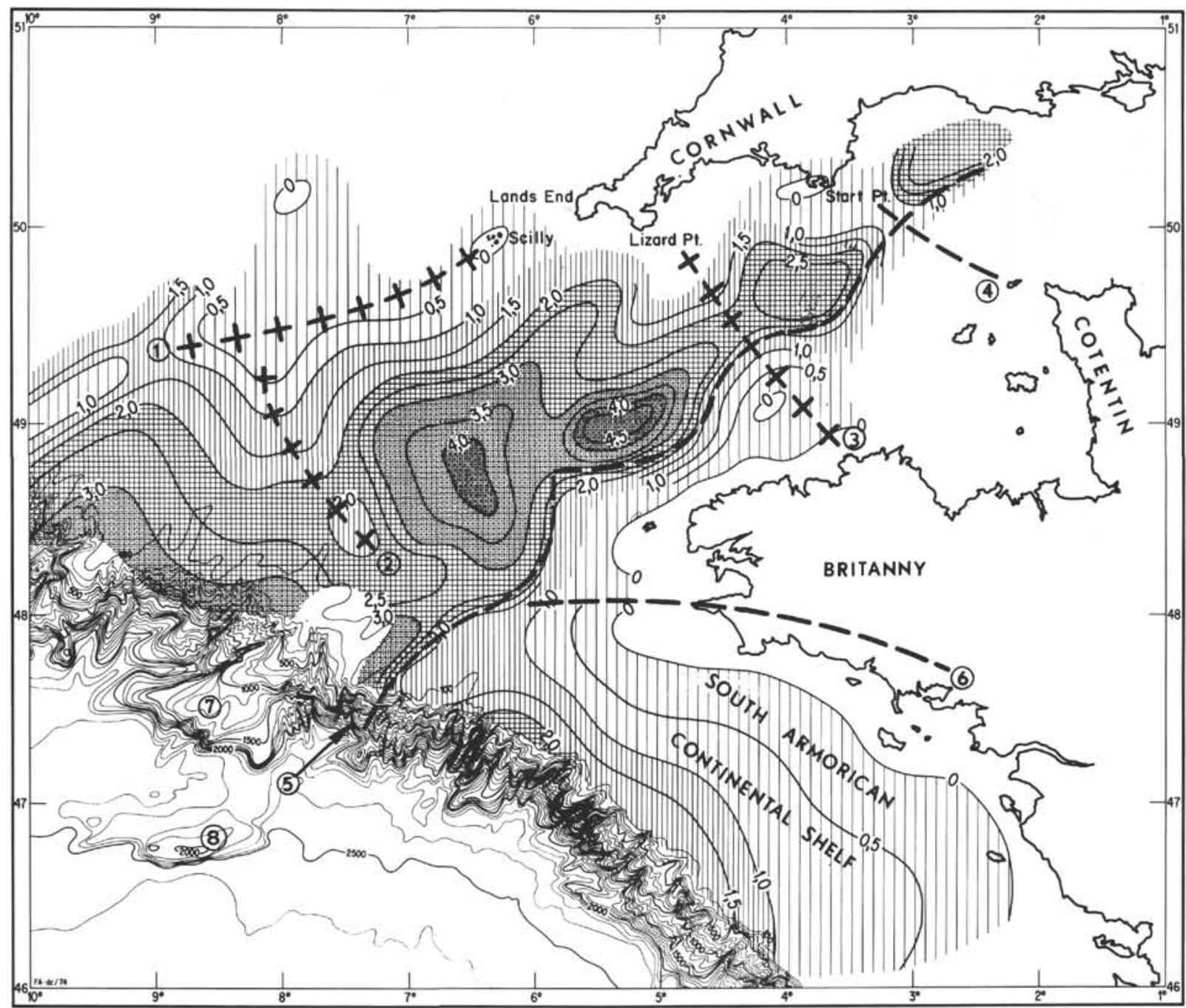

Figure 2. Schematic structure contours in kilometers of the metamorphic basement in the Western Approaches and adjacent areas from Avedik (1975): (1) Lands End granitic batholith ridge; (2) basement ridge coincident at its southeastern end with profiles 11 and 12, of this work; (3) Lizard-Brittany ridge; (4) Start Point-Cotentin ridge; (5) North Armorican Fault; (6) South Armorican shear zone; (7) Meriadzek Terrace; (8) Trevelyan escarpment.

authors, may represent downfaulted continental blocks, the result of a collapsing continental margin.

This downfaulting most likely would be related to the rifting episode of the Armorican continental margin before the opening of the Bay of Biscay, the beginning of which is still debatable (Le Pichon et al., 1971; Montadert et al., this volume). It is also known from previous work that large sedimentary basins stretch along the foot of the continental slope in which the sedimentary thickness is estimated to be about 5 to $6 \mathrm{~km}$.

\section{REFRACTION TECHNIQUE}

The refraction profiles (Figure 1) were reversed or split-spread, their length averaging $70 \mathrm{~km}$. Airguns were used as the seismic source with volumes ranging from 16 to 45 liters (1000 to $\left.2746 \mathrm{in}^{3}\right)$. The seismic detectors were Ocean Bottom Seismographs (Avedik et al., in press). The shot rate was 120 seconds and the ship speed 5 to 6 knots resulting in an average horizontal distance between shots of about 300 meters.

\section{METHOD OF INTERPRETATION}

The multiple dipping planar layer model was adopted for the interpretation. The computation methods of Slotnick (1950) and Johnson (1976) were programmed for the HP 21 MX computer. Using these methods, the interpretation of reversed, split-spread and single-ended profiles could be accommodated.

\section{RESULTS}

The results are discussed under the following headings: (a) Continental Shelf, (b) Meriadzek-Trevelyan complex, and (c) Bay of Biscay at $46^{\circ} \mathrm{N}$ and 6 to $7^{\circ} \mathrm{W}$. 


\section{Continental Shelf}

Two long refraction profiles were shot across the continental shelf by British surveyors. The first profile (profile B), from southwest Ireland towards the Atlantic Ocean, partially crossing the continental slope (Bamford and Blundell, 1969); the second (profile 1), from Lands End over the granite batholith trend, running closely westsouthwest (profile 1 of Holder and Bott, 1971).

From refraction profile $\mathrm{B}$, the estimated depth of the crust-mantle interface is about $30 \mathrm{~km}$ under the continental shelf, rising somewhat ahead of the continental shelf edge to reach a depth of $20 \mathrm{~km}$ under the slope at the end of the profile (water depth $\sim 2000 \mathrm{~m}$ ). Velocity estimates give 8.0 $\mathrm{km} / \mathrm{s}$ for the mantle velocity and $6.0 \mathrm{~km} / \mathrm{s}$ for the mean crustal velocity.

Results of profile 1 yield the following estimates: $\mathrm{Pg}=$ $5.85 \mathrm{~km} / \mathrm{s} ; \mathrm{Pn}=8.07 \mathrm{~km} / \mathrm{s}$, mean crustal velocity $6.2 \mathrm{~km} / \mathrm{s}$; crustal thickness $27 \mathrm{~km}$; dip of Moho insignificant. Holder and Bott suggest an increase of velocity from 5.85 to 6.9 $\mathrm{km} / \mathrm{s}$ in the crust to be in agreement with the measured mean crustal velocity whereas the velocity gradient zone is taken to extend from about 10 to $13 \mathrm{~km}$ to the Moho.

Our reversed profile 11 yields $5.81 \mathrm{~km} / \mathrm{s}$ upper crustal velocity. The mantle could not be penetrated under this profile (profile length only about $90 \mathrm{~km}$ ), but high amplitude arrivals at about 65 to $70 \mathrm{~km}$ from the detector are interpreted as being reflected events from the mantle. This is similar to Holder's and Bott's findings under profile 1. We may conclude then that the mantle under profile 11 should be at about the same depth as that in the area of profile 1 . The measured $5.81 \mathrm{~km} / \mathrm{s}$ velocity under profile 11 suggests that the nature of the upper crust under this profile is also granitic. From this we may postulate that this pronounced basement high is one of the Hercynian arches crossing the Western Approaches and is at a sub-surface depth of about 2 to $2.5 \mathrm{~km}$.

\section{Meriadzek-Trevelyan Complex (Figure 3a)}

Unfortunately, only a short sonobuoy record $(\sim 40 \mathrm{~km})$ is available on the Meriadzek Terrace (profile 06S) leaving a large gap between this profile and the profiles on the continental shelf. The highest velocity of $>5 \mathrm{~km} / \mathrm{s}$ is uncertain due to the fading emission of the buoy resulting in an excessively high noise level. The depth of this interface under profile $06 \mathrm{~S}$ is situated at a depth of about 7 to $8 \mathrm{~km}$ and may represent the basement. Above this interface an approximate $3-\mathrm{km}$-thick layer was found characterized by a $4.4 \mathrm{~km} / \mathrm{s}$ velocity.

At the western end of profile $10,8.2 \mathrm{~km} / \mathrm{s}$ first arrivals were interpreted as belonging to the mantle at a depth of about $12 \mathrm{~km}$. Overlying the mantle is a roughly $3-\mathrm{km}$-thick layer characterized by $6.3 \mathrm{~km} / \mathrm{s}$ velocity. Velocities in the 2.1 to $4.9 \mathrm{~km} / \mathrm{s}$ range represent layers with an overall thickness of about $5 \mathrm{~km}$. At the eastern end of this profile, however, the structure becomes more complex. At $7 \mathrm{~km}$ from the seismometer a fault in the sedimentary layers, downthrowing several hundred meters to the west, is discernible. At $6 \mathrm{~km}$ farther west a much more complex structure exists. Here apparent velocities decrease from 3.8 to $2.2 \mathrm{~km} / \mathrm{s}$ away from the seismometer where the travel direction is from west to east. This velocity decrease is followed by an increase to $5.0 \mathrm{~km} / \mathrm{s}$ after $4 \mathrm{~km}$. A flexuretype structure is envisaged here although the complexity of its representation on the seismic record prohibits any accurate measurements to be made regarding its shape and dimensions.

The split-spread profile 9, situated towards the eastern border of the Trevelyan escarpment, shows great similarities to profile 10 although no mantle penetration was achieved. The highest velocity on its western side was $6.1 \mathrm{~km} / \mathrm{s}$ and on its eastern side $7.9 \mathrm{~km} / \mathrm{s}$. These two arrival branches are interpreted as belonging to the same interface with a true velocity of $6.1 \mathrm{~km} / \mathrm{s}$ as determined from profile D-12. Thus, a computed up-dip of 6 degrees exists on the eastern side of profile 9 for this interface with a near horizontal western side. Under profile 9 , the sedimentary infill, represented by velocities from 2.1 to $5.0 \mathrm{~km} / \mathrm{s}$ decreases slightly with respect to profile 10 . The $5.0 \mathrm{~km} / \mathrm{s}$ layer again shows a dip similar to the underlying layer.

Under profile D-12 (Ewing and Ewing, 1959), the mantle is emplaced at a sub-surface depth of about $12.5 \mathrm{~km}(7.7$ $\mathrm{km} / \mathrm{s}$ ) and above the mantle, a $6.5-\mathrm{km}$-thick layer is present with a velocity of $6.14 \mathrm{~km} / \mathrm{s}$. Only layers in the low velocity class $(1.7$ to $2.24 \mathrm{~km} / \mathrm{s})$ seem to cover the high velocity layer with an overall thickness of about $1.5 \mathrm{~km}$.

Profile 8 was run southwest of the Trevelyan escarpment, at the border of "oceanic" magnetic anomalies. The amplitude of first arrivals on this profile are low (only one 16 liter gun could be used). In addition the correlation of velocities for the deep layers is quite difficult due to their dissimilarities from one detector to the other. The highest velocity obtained is 4.5 to $5.1 \mathrm{~km} / \mathrm{s}$, the top of the $5.1 \mathrm{~km} / \mathrm{s}$ layer being at a depth of 8 to $10.5 \mathrm{~km}$. The velocities of the overlying layers fall in the 2.1 to $3.3 \mathrm{~km} / \mathrm{s}$ range, representing a thickness of about $4 \mathrm{~km}$.

\section{Bay of Biscay (Figure 3b)}

Four profiles are grouped in this area: profile D (of Bacon et al., 1969), profile B of Bacon et al. (1969), and our profiles 1 and $05 \mathrm{~S}$; profile D is oriented east-west, with the detector to the west; the profile of Bacon et al., oriented northwest-southeast is reversed where profile 1 , oriented northwest-southeast, is split-spread.

The isolated sonobuoy profile $05 \mathrm{~S}$ is over the abyssal plain, close to the continental slope, but is more similar to the Meriadzek-Trevelyan group. No apparent "oceanic" layer exists and the mantle was not detected. The mantle under the remaining three profiles of the Bay of Biscay lies at a depth of $11 \mathrm{~km}$, but rises northwards as shown on profile 1 (Figure $3 b$ ). It is overlain by layers of typical "oceanic" velocities.

\section{DISCUSSION}

The free-air gravity anomaly map published by Sibuet (1972) shows $+30 \mathrm{mgal}$ and $+50 \mathrm{mgal}$ anomalies coincident with Trevelyan and Meriadzek, respectively, and equally strong negatives immediately to the north and south of the former. Eastward to the continental slope anomalies are noticeably lacking. Coron et al. (1970) deduce from gravity data that, globally, the area is under isostatic equilibrium. 

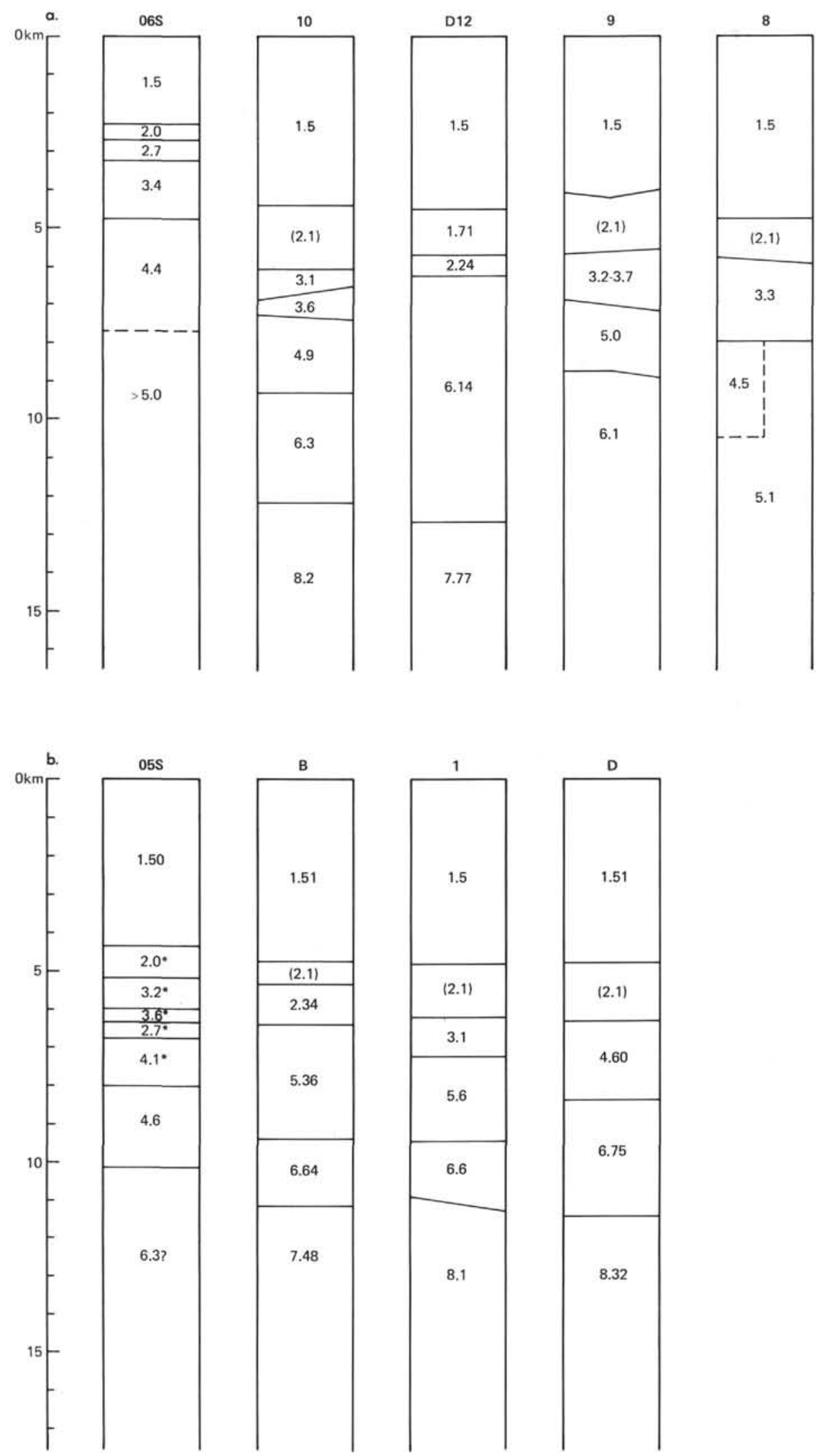

Figure 3. Results of seismic refraction profiles from (a) the Meriadzek-Trevelyan area (b) the Bay of Biscay area. Tabulations from left are north to south, (see Figure 1), and westward is to the left of each column. Numbers in parentheses are assumed from reflection data. 
The total Field Magnetic Anomaly Map (Le Mouël and Le Borgne, 1971) displays some interesting patterns. Firstly, there is a complete absence of short wavelength magnetic anomalies over and east of Trevelyan to the continental slope whereas to its southwest such anomalies are dominant. Secondly, to the north of Trevelyan, under the continental shelf, anomalies of similar signatures predominate but differ in strike direction.

From recent seismic reflection coverage from Meriadzek to Trevelyan, downfaulted typical continental blocks, separated by very low angle faults, are observed (Montadert et al., this volume). In correlating magnetic, gravity, and reflection profiles, these authors suggest that the ocean-continent boundary is located immediately south of the Trevelyan escarpment, itself reactivated during a later Eocene compressive episode.

Analysis of results from the seismic refraction studies of the Meriadzek-Trevelyan area establish four main velocity groups overlying the mantle of average velocity $8.15 \mathrm{~km} / \mathrm{s}$ : (a) 1.9 to $2.8 \mathrm{~km} / \mathrm{s}$, (b) 3.2 to $4.0 \mathrm{~km} / \mathrm{s}$, (c) 4.5 to $5.0 \mathrm{~km} / \mathrm{s}$, (d) 5.4 to $6.3 \mathrm{~km} / \mathrm{s}$.

The first group is found under all profiles and assumes a thickness of between 1 and $1.7 \mathrm{~km}$. The second velocity group varies in thickness from 1 to $2 \mathrm{~km}$ but is apparently absent under profile D12. Its thickest development is immediately to the southwest of the Trevelyan escarpment. Group three, a 2 to $3 \mathrm{~km}$ thick layer, is detected at depths between 5 and $7 \mathrm{~km}$. Its maximum thickness is in the Meriadzek area, but it thins southwestwards from $3 \mathrm{~km}$ to about $2 \mathrm{~km}$ under profile 9 and is again found to be lacking under profile D 12. A velocity falling within this group is detectable only on the western end of profile 8 . The thickness and depth of the fourth velocity group is best defined between Meriadzek and Trevelyan. Under profiles 9 and 10 it lies at a depth of about $9 \mathrm{~km}$ with a thickness of 3 $\mathrm{km}$ but under profile D 12 this thickness increases rather abruptly to $6 \mathrm{~km}$. On the Meriadzek terrace itself this layer is at a depth of $8 \mathrm{~km}$, but its depth to base is unknown. Again, no comparable velocity is seen for profile 8 .

Unpublished results from a profile (Whitmarsh, cf. Bacon and Gray, 1971) immediately to the south of profile 8 show a similar mantle depth $(12 \mathrm{~km})$ to that of profiles D 12 and 10 . Under the continental shelf area and the adjoining French mainland, the average mantle depth is well established between 27 and $30 \mathrm{~km}$ (cf. Bott and Watts, 1970; Holder and Bott, 1971; Sapin and Prodehl, 1973). The high-energy mantle reflections on profile 11 , at about the same horizontal distance as on profile 1 of Holder and Bott, suggest a mantle depth of about $27 \mathrm{~km}$. If the mantle has a similar behavior to that reported by Bamford and Blundell (1970) for the Porcupine Bight area, a mantle rise southwestward from 27 to $12 \mathrm{~km}$ across the Armorican Continental slope would be expected.

Because the present area is considered to be under isostatic equilibrium, it would be expected that a linear relationship exists between the depth of the mantle and the overburden pressure at this level. A depth-pressure diagram drawn up from 9 different profiles and based on the compressive velocity-density relationship of Nafe et al. (1970) is shown on Figure 4. It clearly shows the expected linear relationship from an isostatically balanced region.

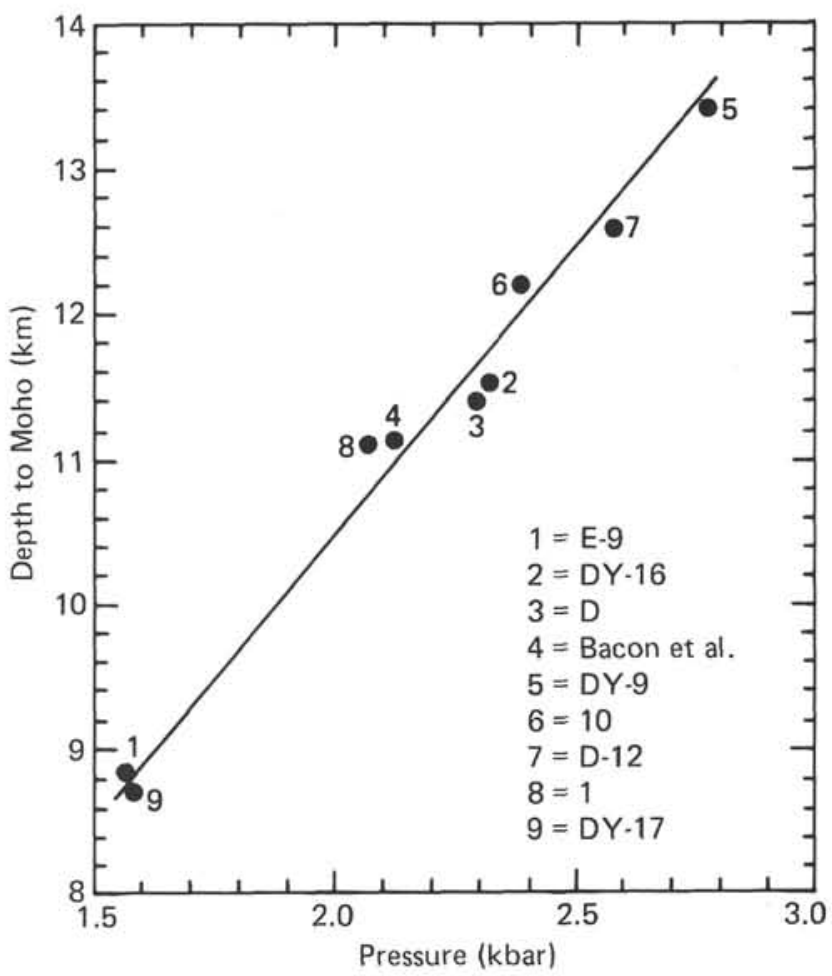

Figure 4. Diagram representing overburden pressure versus depth of Moho. Profiles DY9, 16, 17 from Hill and Laughton (1952), profile E-9 from Ewing and Ewing (1959); the remaining profiles are as shown in Figure 1. DY9: $48^{\circ} 20^{\prime}, N, 11^{\circ} 20^{\prime} \mathrm{W}$; DY16: $47^{\circ} 48^{\prime} \mathrm{N}, 13^{\circ} 20^{\prime} \mathrm{W}$; DY17: $48^{\circ} 21^{\prime} \mathrm{N}, \quad 16^{\circ} 49^{\prime} \mathrm{W} ; \quad \mathrm{E9}$ : $45^{\circ} 52^{\prime} \mathrm{N}, 15^{\circ} 23^{\prime} \mathrm{W}$.

This in turn means that the mantle depth has been deduced correctly from the seismic refraction measurements.

The model shown in Figure 5 for the Trevelyan area was suggested by Bacon and Gray (1971) from their gravity studies. Their mantle-depth determination agrees with the depth-pressure diagram.

The relatively high velocities ( 6.1 to $6.3 \mathrm{~km} / \mathrm{s})$ typical of continental crustal rocks obtained between Trevelyan and Meriadzek, coupled with the lack of magnetic anomalies, strongly suggest that this area is of continental-type material. These velocities are somewhat lower than those observed in the corresponding layer (i.e., immediately overlying the mantle) in areas where short wavelength "oceanic" magnetic anomalies dominate. Under the Bay of Biscay profiles, D, 1, and B (Figure 1), the mantle has directly overlying it oceanic material characterized by the velocity range 6.6 to $6.75 \mathrm{~km} / \mathrm{s}$. Magnetic anomalies, as expected, cover this area. A thin 1.5 to $2.5 \mathrm{~km}$ sedimentary layer exists here and thickens northward towards profile $05 \mathrm{~S}$ which has a similar sedimentary layer configuration to that of profiles 8 and 10 . These last profiles are coincident with negative gravity anomalies interpreted as a result of basinal features.

The similarity of the sedimentary layers could suggest an eastward prolongation of these basins towards the continental slope from Trevelyan. The apparent absence of oceanic material under the sonobuoy profile $05 \mathrm{~S}$ (Figure 

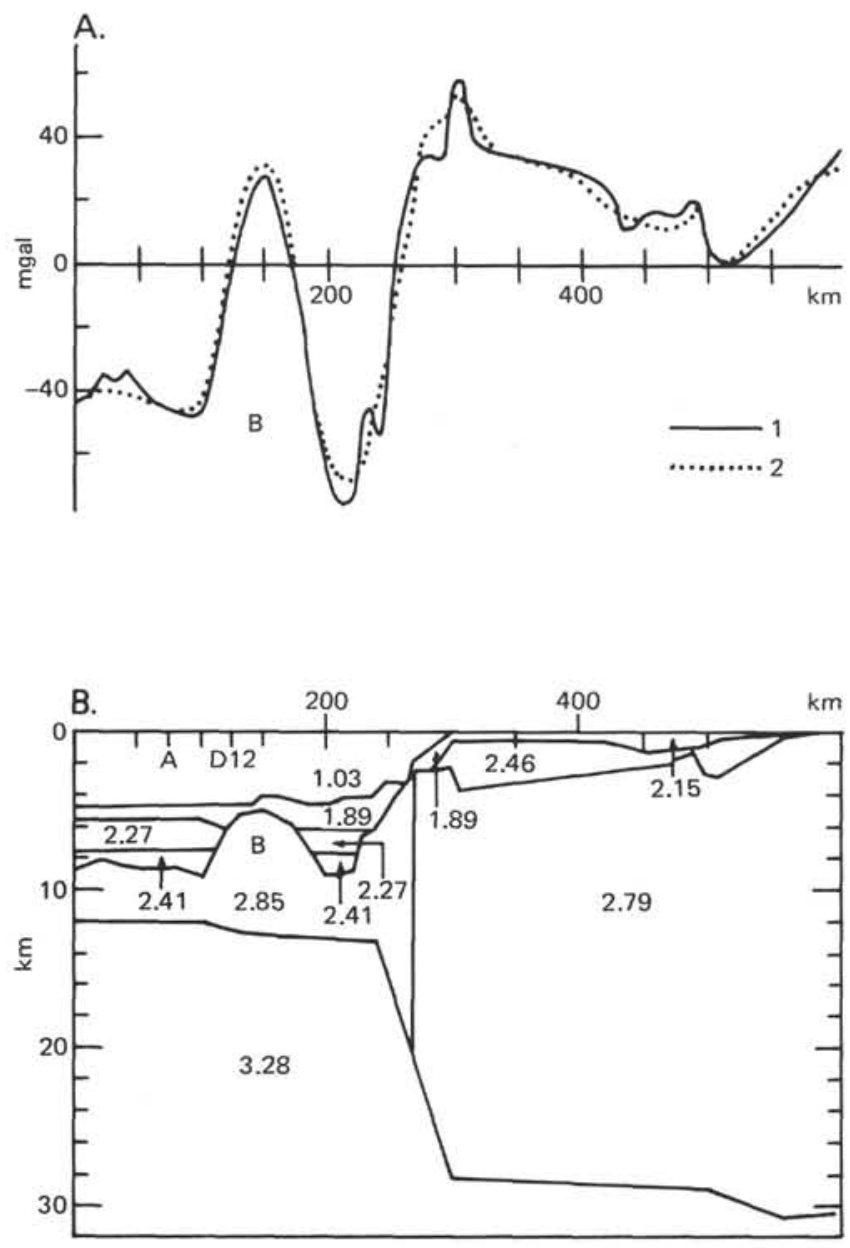

Figure 5. (A) observed (1) and calculated (2) free-air gravity anomalies along the dotted track shown in Figure 1. (B) two-dimensional model calculated to fit the observed gravity of $(A)$. Figures are densities in $\mathrm{g} / \mathrm{cm}^{3}$ (from Bacon and Gray, 1971).

$3 \mathrm{~b})$, the bathymetric trends towards Trevelyan, the lack of magnetic anomalies, and the seismic reflection features of Montadert et al., (1974) all suggest that this region may also be of continental-type material. Continental granitic basement has been sampled at the foot of the slope on the western part of the margin near $48^{\circ} \mathrm{N}, 12^{\circ} \mathrm{W}$ at a comparable depth to the Trevelyan area (Pautot et al., 1976; Didier et al., 1977; Auffret et al., this volume).

It therefore appears that the continental structure does stretch out as far west as the Trevelyan escarpment, i.e., a horizontal prolongation of about $140 \mathrm{~km}$ of the continental slope is envisaged. Examination of the depths and thicknesses from the various profiles indicates geological discontinuities occurring between profiles $06 \mathrm{~S}$ and 10 and again between profiles D12 and 8. The Meriadzek and Trevelyan escarpments, respectively, are likely to be surface representations of these discontinuities. Little is known of the sub-structure between profiles $06 \mathrm{~S}$ and 11 owing to lack of data, and although large differences exist in the depths and thicknesses across this gap, a block-faulted setting may also be envisaged here. From topographic considerations the escarpment to the northeast of profile $06 \mathrm{~S}$ could be interpreted as a surface representation of the edge of one of these blocks.

All these continental blocks, resting directly on the mantle, are considered as the result of rifting of the Armorican continental margin.

\section{GEOLOGICAL MODEL}

It is now desirable to attempt to assign the velocity groups delineated in the present work to different geological layers. This may be done by correlation with other known areas. Because the Meriadzek-Trevelyan area is considered to be of continental origin and lacks similarity with the Bay of Biscay profiles over an apparent oceanic region, it seems logical to compare it with the adjoining and much surveyed areas of the Western Approaches and the English Channel (Avedik, 1975; Holder and Bott, 1971; Naylor and Mounteney, 1975; Hill and Laughton, 1952; cf. Bott and Watts, 1970).

Here a thin superficial layer, of $0.5 \mathrm{~km}$ average thickness, constitutes Cenozoic sediments characterized by the velocity range 1.9 to $2.5 \mathrm{~km} / \mathrm{s}$. The Upper Cretaceous is well represented under a Tertiary cover in the Western Approaches, but the Lower Cretaceous may occur only locally as thick sequences. From velocity measurements on Cretaceous outcrops, refraction and reflection studies suggest the velocity range 2.6 to $3.9 \mathrm{~km} / \mathrm{s}$ for this period. The Cretaceous is interpreted as 0.5 to $1.5 \mathrm{~km}$ thick and is detected up to the continental edge. It blankets the entire Western Approaches and begins to thicken to its maximum immediately to the northeast of Meriadzek towards the southwest. The Cretaceous is partly underlain by an intermediate sequence of velocity 3.6 to $4.3 \mathrm{~km} / \mathrm{s}$ and partly by a sequence characterized by a 4.4 to $5.0 \mathrm{~km} / \mathrm{s}$ velocity range. The former was interpreted as Mesozoic and the latter as lower to middle Paleozoic. However, in light of recent geological and geophysical information in the Western Approaches, the layer labeled as Paleozoic does now appear to be Jurassic and possibly Permo-Triassic in age. The thickness of this layer is most variable as it appears to fill depressions in the underlying metamorphic and igneous basement. It probably assumes its least thickness near the Meriadzek Terrace.

Underlying these sediments is the metamorphic basement comprising rocks in various stages of metamorphism and often associated with acid and basic intrusives. The velocities of this basement ( 5.3 to $6.6 \mathrm{~km} / \mathrm{s}$ ) agree well with those of metamorphic and igneous rocks of the adjacent land areas. Near Meriadzek and profile 11 (Figure 1), the basement is at a depth of about $3 \mathrm{~km}$ but remains continually within $5 \mathrm{~km}$ of the surface over the entire continental shelf of this area.

Although velocities cannot be used in themselves as a basis for establishing clear-cut distinctions between geological periods, nevertheless the foregoing observations of the geology of the Western Approaches and the Channel areas show a similarity between the established velocity groups there and those obtained in the Meriadzek-Trevelyan area. It appears also that the sequences obtained in the former area can be continued to the Trevelyan escarpment. The velocity groups of the present area may thus be broadly 
classed as follows: 1.9 to 2.8 , Cenozoic; 3.2 to 4.0 , Cretaceous; 4.5 to 5.0 , Jurassic to Permo/Triassic; 5.4 to 6.4, Igneous and metamorphic basement.

The presence of a Permo-Triassic layer is interesting as this suggests the presence of a graben-type feature at this age or older which in turn would have resulted from rifting of the Armorican continental margin.

A schematic geological model based almost exclusively on seismic observations is shown in Figure 6 and represents the substratum configuration for the profile $A B C$ on Figure 1. The block-faulted pattern between Meriadzek and Trevelyan, as discussed above, is based largely on seismic reflection data. Cretaceous strata, although not detected under D 12, are nevertheless inserted here purely on plausible geological grounds (Figure 6).

The geological model is quite similar in many respects to the model suggested by Bacon and Gray (1971) from their gravity studies (Figure 5). They predict also a non-magnetic basement ridge under the Trevelyan escarpment flanked on either side by sedimentary basins with similar layers, whose bases lie between 9 and $10 \mathrm{~km}$. This ridge has associated with it the positive free-air gravity anomaly of $30 \mathrm{mgal}$. These same authors conclude that the whole region is a downfaulted thinned crust. A downfaulting process at the continental margin was first suggested by Day (1959) and later by Cholet et al. (1968). It cannot be stated with certainty whether this downfaulting process has itself caused a thinning of the crust or whether the crust was originally thin.

If the crust between Meriadzek and Trevelyan is taken as purely a prolongation of the original continent, then its thickness here is a function solely of the emplacement of these blocks, i.e., these blocks are collapsed features from a continental edge. Under this hypothesis the relatively large block or blocks directly under the Trevelyan escarpment may have had a somewhat different emplacement history.

\section{CONCLUDING REMARKS}

From the foregoing discussion, the data from the various geophysical methods applied to this area afford a feasible geological picture of the sub-surface structure. All the available evidence points to the nature of Trevelyan as being of continental material. Such a continental prolongation is known to occur only in this region. The South Armorican shear zone, of Hercynian age, stretching across southern Brittany towards the Meriadzek Terrace (Figure 2), may have tectonized the continental margin area in such a way as to influence the actions of late tectonic events to produce the present form of Trevelyan.

If the area east towards the continental slope is also of continental-type material, as hypothesized earlier in this discussion, then its prolongation southwestward could also be envisaged as indirectly influenced by the shear zone. The block representation of the basement (Figure 6) is based on good geophysical evidence but nevertheless must remain schematic, being based largely on the results of only three refraction profiles. In addition, accepting its hypothesized tectonic origin, it will be a very complex region in detail. Finally, the results presented here should act as a guide and reference to further work carried out in this and similar environments.

\section{ACKNOWLEDGMENTS}

The authors gratefully acknowledge the assistance given by the officers and crew of the N/O Jean Charcot during the cruises. We also thank J.C. Sibuet and P. Guennoc for critically reading the manuscript, S. Monti for the draft work, and Y. Potard and N. Guillo for the typing.

D. Howard acknowledges the financial assistance from C.I.E.S., Paris.

\section{REFERENCES}

Avedik, F., 1975. The seismic structure of the Western Approaches and the South Armorican continental shelf and its

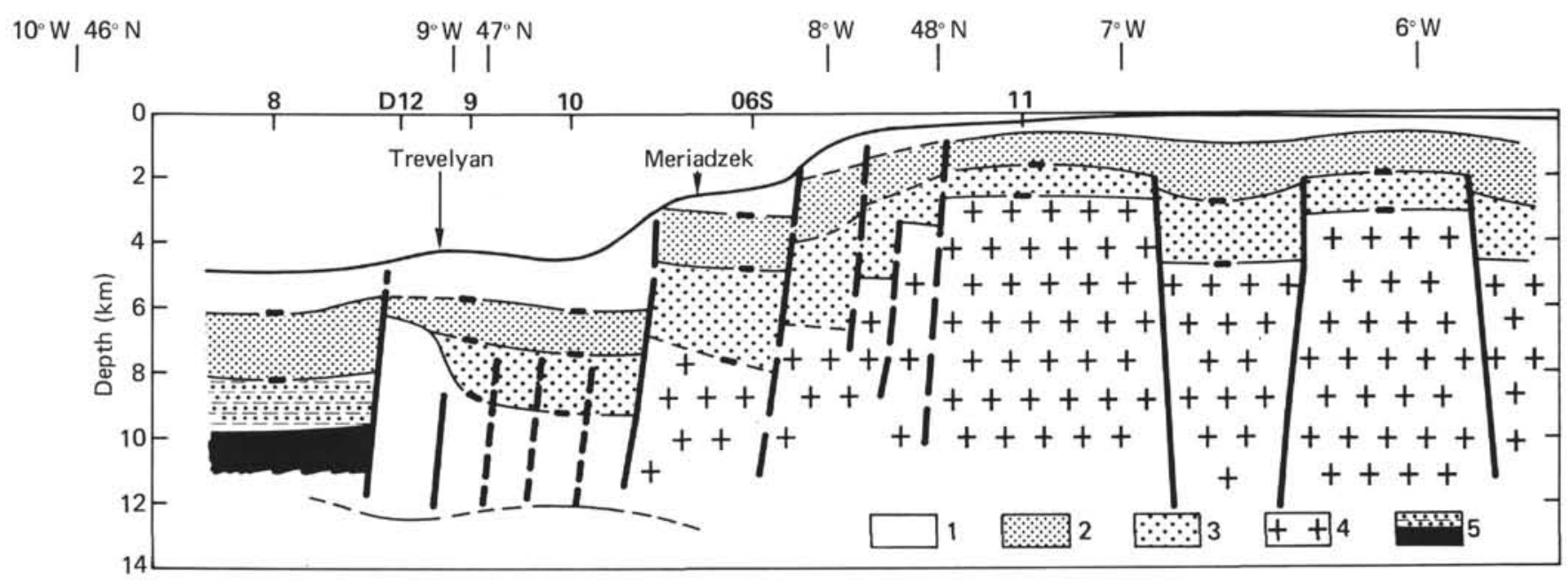

Figure 6. A schematic geological cross-section along the line A-B-C of Figure 1 based on the results of seismic refraction and reflection studies of the present and previous work. $1=$ Cenozoic $; 2=$ Cretaceous; $3=J$ urassic, Permo-Trias; $4=$ Metamorphic and igneous basement; 5 = Oceanic layers. 
geological interpretation. In Woodland, A.W. (Ed.), Petroleum and the continental shelf of North West Europe: v. 1.

Bacon, M. and Gray, F., 1971. Evidence for crust in the deep ocean derived from continental crust, Nature, v.229, p. 331-332.

Bacon, M., et al., 1969. Crustal structure studies in the Bay of Biscay, Earth Planet. Sci. Lett., v. 6, p.377-385.

Bamford, S.A.D. and Blundell, D.J., 1970. Southwest Britain Continental Margin Experiment. In Delany, F.M. (Ed.), The geology of the East Atlantic Continental Margin: Institute of Geological Sciences Report 70/14, p. 143-156.

Bott, M.H.P. and Watts, A.B., 1970. Deep Structure of the Continental Margin adjacent to the British Isles. In Delany, F.M. (Ed.), The geology of the East Atlantic Continental Margin: Institute of Geological Sciences Report 70/14, p. 89-109.

Cholet, J., Damotte, B., Grau, G., Debyser, J., and Montadert, L., 1968. Recherches préliminaires sur la structure géologique de la marge continentale du Golfe de Gascogne. Commentaires sur quelques profils de sismique réflexion "Flexotir," Rev. Inst. Franç. Pétrole, v. 23, p. 1029-1045.

Coron, S., Guillaume, A., and Bouvet, J., 1970. Contribution gravimétrique à l'étude du Golfe de Gascogne, C.R. Acad. Sci. Paris, v.271, p. 756-759.

Davey, F.J., 1970. Bouguer anomaly maps of the North Celtic Sea and entrance to the British Channel, Geophys. J. Roy. Astron. Soc., v. 22, p. $277-282$.

Day, A.A., 1959. The continental margin between Brittany and Ireland. Deep-Sea Res., v. 5, p. 249-269.

Didier, J., et al., 1977. Granodiorites, gramulites et charnockites de l'éperon de Goban (marge armoricaine) au contact du domaine océanique, C.R. Acad. Sci. Paris, v. 284, p. 713-716.

Ewing, J. and Ewing, M., 1959. Seismic refraction measurements in the Atlantic Ocean Basins in the Mediterranean Sea, on the Mid-Atlantic Ridge, and in the Norwegian Sea, Geol. Soc. Am. Bull., v. 70, p. 291.

Hill, M.N. and Laughton, A.S., 1952. Seismic observations in the Eastern Atlantic, Roy. Soc. London Proc., v. 222, p. 348-356.
Holder, A.P. and Bott, M.H.P., 1971. Crustal structure in the vicinity of South-West England, Geophys. J. Roy. Astron. Soc., v. 23 , p. 465-489.

Johnson, S.H., 1976. Interpretation of split-spread refraction data in terms of plane dipping layers, Geophysics, v. 41, p. 418-424.

Le Mouël, J.L. and Le Borgne, E., 1971. La cartographie magnétique du Golfe de Gascogne. In Debyser, J., Le Pichon, $\mathrm{X}$., and Montadert, L. (Eds.), Histoire structurale du Golfe de Gascogne: Technip (Paris), v. 2, p. 1-11.

Le Pichon, X., Bonin, J., Francheteau, J., and Sibuet, J.C., 1971. Une hypothèse d'évolution tectonique du Golfe de Gascogne. In Debyser, J., Le Pichon, X., and Montadert, L. (Eds.), Histoire structurale du Golfe de Gascogne: Technip (Paris), v. 2, p. 1-44.

Le Pichon, X., Sibuet, J.C., and Francheteau, J., 1977. The fit of continents around the North Atlantic Ocean, Tectonophysics, v. 38, p. 169-209.

Montadèrt, L., Winnock, E., Delteil, J.R., and Grau, G., 1974. Continental margins of Galicia-Portugal and Bay of Biscay. In Burk, C.A. and Drake, C.L. (Eds.), The Geology of continental margins: New York (Springer-Verlag), p. 323-342.

Nafe, J.E., 1970. Lamont-Doherty Observatory. In Ludwig et al. (Eds.), The sea: New York (Wiley-Interscience), v. 4.

Naylor, D. and Mounteney, S.N., 1975. Geology of the North-West European Continental Shelf: Graham (Trotman Dudley Ltd.), v. 1, p. 57-65.

Pautot, G., Renard, V., Auffret, G., Pastouret, L., and De Charpal, O., 1976. A granite cliff deep in the North Atlantic, Nature, v. 263 , p. 669-672.

Sapin, M., and Prodehl, C., 1973. Long range profiles in Western Europe, I, Crustal structure between the Bretagne and the Central Massif of France, Ann. Géophys., v.29, p. 127-145.

Sibuet, J.C., 1972. Contribution de la gravimétre à l'étude de la Bretagne et du plateau continental adjacent. C.R. Sommaire des séances de la Société Géologique de France, Fasc. 3, p. 124-129.

Slotnick, M.M., 1950. A graphical method for the interpretation of refraction profile data, Geophysics, v. 25, p.103-180. 